\title{
THE RADIOCARBON CALIBRATION FROM AN IRISH OAK PERSPECTIVE
}

\author{
Mike G L Baillie \\ Palaeoecology Centre, School of Geosciences, Queen's University, Belfast, Northern Ireland, United Kingdom. \\ Email: mbaillie@queens-belfast.ac.uk.
}

\begin{abstract}
Between 1968 and 1984, a 7272-yr oak chronology was constructed in Belfast, Northern Ireland, in order to provide a local calibration of the radiocarbon timescale. This single-minded exercise in chronology construction provided an exciting occupation for a group of researchers that can be likened to a race in which there was no guarantee of a finish. The existence of a parallel dendrochronological enterprise in Germany added both competition and the possibility of independent replication. The initial completion of both chronologies by 1984, and respective calibrations by 1986, left an important legacy of 2 absolutely dated tree-ring chronologies for multifarious research purposes.
\end{abstract}

\section{THE STORY}

In the mid-1960s, a radiocarbon setup was acquired by the environmental research unit known as the Nuffield Laboratory (later to become the Palaeoecology Centre) at Queen's University, Belfast, the principal idea being the production of a ${ }^{14} \mathrm{C}$ timescale for Holocene peat and lake deposits within the north of Ireland. At the time, large-scale drainage and road construction operations, cutting through peat bogs, were throwing up large numbers of subfossil oak and pine trunks. Observation of this Holocene resource led Alan Smith and Jon Pilcher to speculate on the possibility of constructing a long Irish tree-ring chronology - and an Irish ${ }^{14} \mathrm{C}$ calibration - specifically to answer the questions raised by the American calibration curve produced by Hans Suess (1970). This is an excellent example of the coming together of circumstances to foster innovative research: right time, right place, right equipment, suitable intellectual environment.

One outcome of deliberations at the time was the acquisition of new personnel dedicated to the ${ }^{14} \mathrm{C}$ and tree-ring aspects of the prospective calibration exercise; these were Gordon Pearson and this author, respectively. Both arrived to take up positions in the ${ }^{14} \mathrm{C}$ laboratory on 1 August 1968; Pearson as a Research Officer, Baillie as a part-time Research Assistant. The secret of universities back in those days was their flexibility; while Pearson was employed full time on refinement of ${ }^{14} \mathrm{C}$ measurement, which was to lead to a full-blown high-precision ${ }^{14} \mathrm{C}$ setup (Pearson 1980), the part-time position in the ${ }^{14} \mathrm{C}$ lab allowed Baillie, working with Pilcher, to begin serious exploration of the possibility of building a long (target 6000-7000 yr) tree-ring chronology, i.e. no one was actually employed to work on the tree-ring project; it was initiated informally.

Up to 1968 , there had been no tree-ring work in Ireland and essentially none in Britain. The early American work of Douglass (1919) was known, as were the limited oak chronologies that had been extended back approximately 1000 yr in Germany (Hollstein 1965; Huber and Giertz 1969). However, the successful application of dendrochronology elsewhere had to be balanced by the fact that leading paleoecologists - Harry Godwin in England and Frank Mitchell in Ireland - believed that the method would not work in the British Isles because of the "wet climate." Both seem to have taken the success of dendrochronology in the American Southwest as implying that the method would only work in semi-arid areas. This negative assumption meant that chronology construction in Belfast was taken back to its most fundamental principles. Could dendrochronology be made to work successfully in the small geographical area represented by the relatively mild and damp north of Ireland? This has been likened to a "black box" approach. Because researchers like Godwin and Mitchell could come up with a long list of reasons why the method would not work (insect attack, site differences, site aspect, wind, weather, subspecies differences, etc.), it was decided to tackle the 
problem differently. All the worry about tree-ring patterns not matching was driven by attempts to understand factors that might influence tree growth; this is a biological approach. A more physical approach would be as follows. Why not treat tree growth as a "black box" wherein it does not matter why trees have a pattern of growth? Just look at the tree-ring patterns and see if they can be made to cross-match. In other words, irrespective of all the reasons why the method might not work, was it possible to cross-match their ring patterns anyway?

Two strands of research were initiated. First, random samples of subfossil oak and pine were acquired from numerous bog and lake-edge sources and submitted for ${ }^{14} \mathrm{C}$ analysis. This established that pine offered no possibility of a long chronology as it was essentially extinct in Ireland between the mid-3rd millennium BC and the 17th century AD (Smith et al. 1972). On the other hand, the ${ }^{14} \mathrm{C}$ results showed that oaks were available from all periods back to at least $5000 \mathrm{BC}$. This random sampling approach established that as far as sample availability was concerned, an oak chronology had to be a possibility. Secondly, modern oaks were sampled from estates across Northern Ireland and an assessment was made of the crossdating potential for these known-age ring patterns. This work uncovered the fact that Irish oak ring patterns could not be reliably crossdated by procedures such as skeleton plotting (used in the arid American Southwest [Stokes and Smiley 1968]) or the use of "percentage agreement" computer crossdating as practiced with German oak (Eckstein and Bauch 1969). Instead, a computer program was developed (modeled in some ways on the manner in which the human eye assesses similarity between jagged graphs) that could reliably pick out the correct matching position between Irish oak ring patterns with a uniquely high correlation value. This CROS program (Baillie and Pilcher 1973), when combined with visual matching, allowed highly reliable crossdating, and variants are still in widespread use today (Munro 1984).

Thus, the outcome of this early exploratory work was the recognition that Irish oak was a good candidate for dendrochronological work, and oak samples were potentially available for several thousands of years. With this knowledge (and a chainsaw plus a primitive measuring stage good to $0.05 \mathrm{~mm}$, and a mainframe computer, and plenty of time), serious chronology construction began in Belfast. The approach broke down into 2 main thrusts. One of these concentrated on extending the modern chronology back for the last 2 millennia or so; the other was devoted to the first 5 millennia $\mathrm{BC}$. This split was dictated by 2 factors. The ${ }^{14} \mathrm{C}$ dating exercise had shown that the vast majority of subfossil oaks were prehistoric; in Ireland this means they are mostly restricted to the $\mathrm{BC}$ era. Thus, an approach had to be developed for building a long subfossil chronology where there were almost no guidelines as to the age of any sample. In contrast, for the last 2 millennia historical and archaeological timbers were available from contexts where some information was available to act as a broad guide to likely sample age.

\section{THE AD PERIOD}

The construction of a modern era oak chronology in Ireland was never going to be easy. Unlike most other European countries, Ireland has a history that has militated against the survival of buildings and their documentation. In Germany, for example, the construction of a 1000-yr chronology was facilitated by the existence of thousands of complete medieval buildings often with well-documented construction dates (see e.g. Hollstein 1980). In contrast, in Ireland few medieval buildings survive with timbers intact and there is a notable lack of good documentation. With respect to 1st millennium archaeological sources, even the best studied sites would not normally be datable to better than a century or two using available archaeological methods. Moreover, it was discovered that the very oldest living oaks available in Ireland ran back only to the mid-17th century. The result was that chronology building proceeded as follows: robust, well-replicated sections of chronology were constructed and subsequently linked. These were the "modern," "late medieval," "high medieval," 
and "Early Christian" chronology sections. To give just 1 detailed example, the first link in the Irish long chronology - that from living trees to post-medieval timbers - was forced to depend on a very short 68-yr overlap (1649-1716). While this extended chronology ran back satisfyingly to the mid14th century, unfortunately the length of overlap was too short to give confidence to the linkage. This clearly required additional evidence and here the Belfast team's experience was to stand us in good stead later. In order to confirm the AD 1649-1716 linkage, we acquired long-lived oak samples to build chronologies in both Scotland (Cadzow Forest) and England (Sherwood Forest). These modern chronologies ran back to AD 1444 and 1425, respectively, and both chronologies crossmatched significantly with the AD 1350-1716 Irish section, confirming the dating precisely, and telling us a lot about the geographical extent of crossdating for oak. This exercise was important in providing confidence in our procedures - and confidence was going to be an important issue as we extended back into the unknown mists of early history and prehistory.

Linking across the other problem, "join periods" in the mid-14th and mid-9th centuries each had their own adventures; however, by the early 1980s each had been successfully bridged, and a fullyreplicated oak chronology complex for the British Isles, based round the Belfast chronology, existed back to 13 BC (Baillie et al. 1983) (see Figure 1).

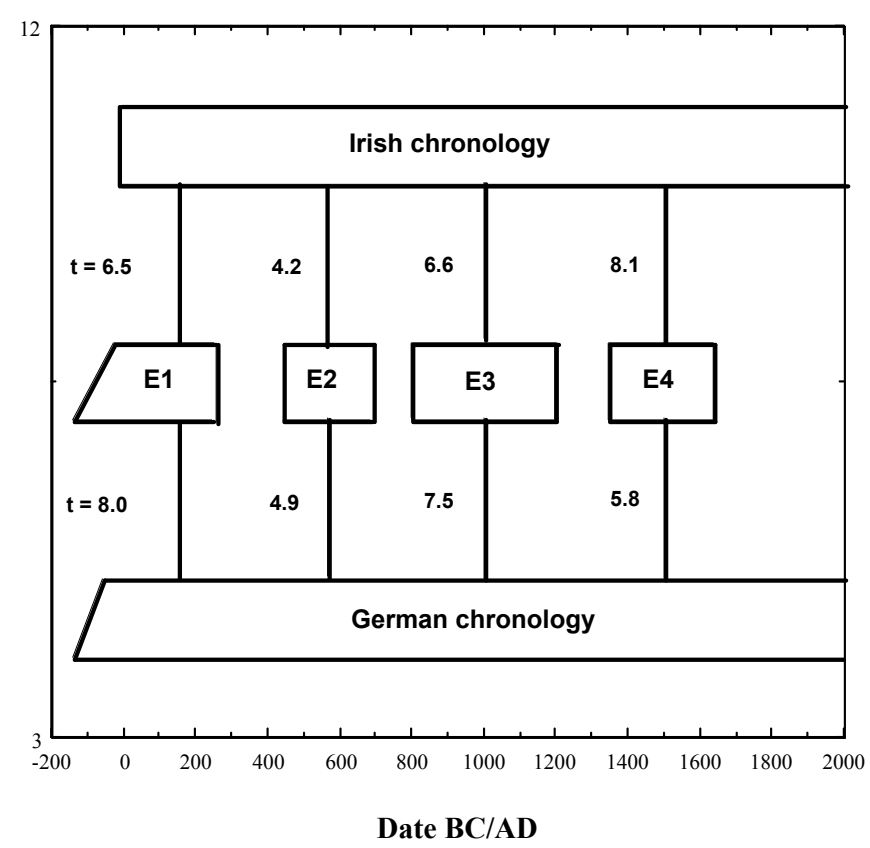

Figure 1 Schematic diagram showing consistent stepwise correlations from the independent Irish oak chronology, through English chronology sections, to the German oak chronology (after Baillie 1995: Figure 1.11).

\section{THE BC ERA CHRONOLOGY}

Bog oaks occur widely in Irish peat bogs. They are referred to colloquially as "black oak" due to the fact that iron in the groundwater tends to stain the wood black. They originally grew on the surface of living peat bogs; eventually they blew down and were buried in the peat. There are no good modern parallels for this presence of long-lived oaks growing on the surface of peat bogs! No one has ever understood why they are there, but irrespective of their survival history, they form an incredible 
environmental resource. The biggest problem in trying to build chronologies using bog oaks is that the oaks themselves offer no clues as to relative age; one bog oak looks very like any other, and appearance is no guide to age. This problem was made even more difficult by the fact that the timbers were normally not found in situ in the bogs; rather, they were almost always found in heaps after they had been dragged out by heavy machinery (see Figure 2). So the problem initially appeared as follows. There were thousands of bog oaks of Holocene age, but they were unstratified and there was nothing to indicate either absolute age or indeed relative age.

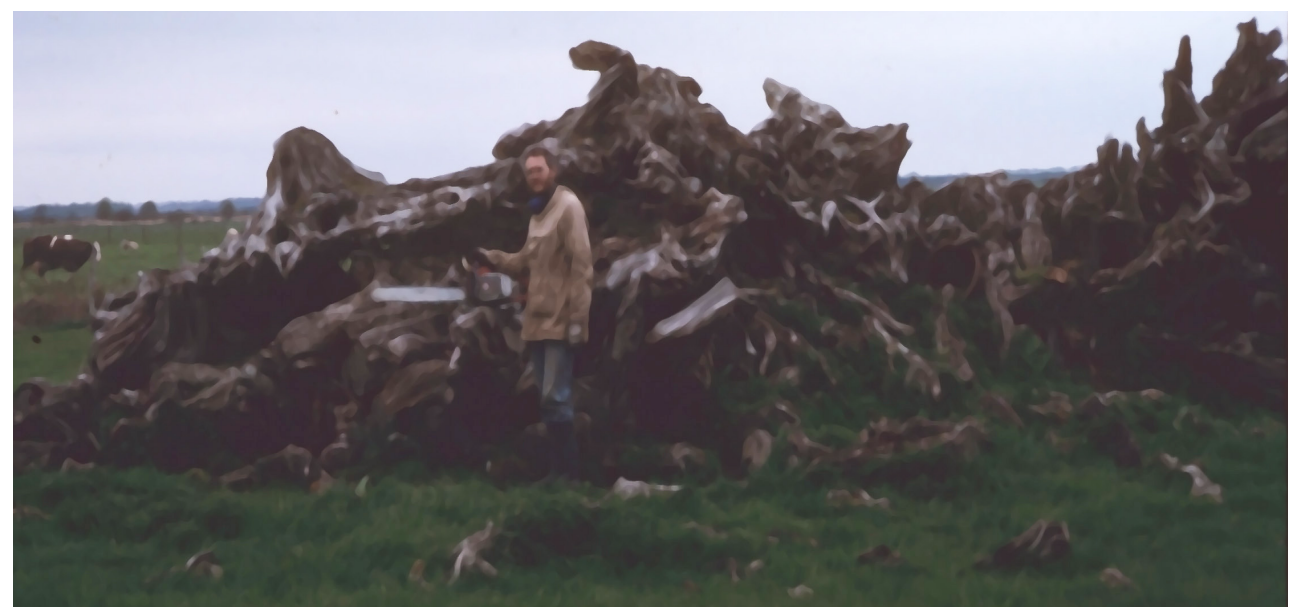

Figure 2 A group of subfossil (bog) oaks from Garry Bog, Northern Ireland, pulled out during land drainage. Most of the trees in this group grew in the 1st millennium BC.

Any sensible group might have had second thoughts given these constraints-a 5000- or 6000-yr "jigsaw" to build and no "picture on the box." However, the Belfast team, which after 1970 included Jennifer Hillam, saw this as a challenge. We did have some advantages. Irish bog oaks were very slow grown, probably because of poor nutrient status on the bog surfaces, though possibly also due to their genetic strain. The grand mean ring width from thousands of such trees is just $1 \mathrm{~mm}$; the typical age is around $250 \mathrm{yr}$ with occasional examples up to $350 \mathrm{yr}$ and oddities up to 450 . Apart from the advantage of long ring patterns, we also had some ${ }^{14} \mathrm{C}$ dates to provide a broad chronological framework, but that was not the secret to success in prehistoric chronology construction. The secret was logic combined with trial and error.

Logic suggested the following. Imagine we sampled 40 bog oaks and each on average had 250 rings. If none of them crossdated, then they could be laid out end to end as $40 \times 250$-yr sections, i.e. some 10,000 yr of "chronology." But, we already knew that the bog oaks were mostly restricted to about 5000 or $6000 \mathrm{yr}$. It was pretty certain that if we kept on measuring these long-lived oaks, eventually some of them would have to cross-match!

That is what we did; we kept measuring, and to our surprise we did not have to measure 40 , or even 20 , trees before we started finding cross-matches. On the very first site, before we got to 10 trees, we had established cross-matching. To cut a long story short, what we discovered was that at least some of the trees on any site tended to be closely related in time. The trees were not random in age; rather, they represented the remnants of regenerating woodlands on the bog surfaces. So, very quickly we discovered that a single farmer's field yielding perhaps 50 trees could provide a site chronology spanning 500-1000 yr. All of this meant that the task of building a prehistoric bog-oak chronology reduced to the construction of numerous super-long site chronologies. It all took time, and luck, but 
by the stage that the $\mathrm{AD}$ era chronology was complete back to $13 \mathrm{BC}$, the prehistoric situation had reduced to 3 major chronological sections spanning roughly 5000-4000 BC, 4000-1000 BC, and 1000-200 BC. Indeed, by 1983 the 2 earliest chronologies had been linked and the problem of the prehistoric chronology had changed from "how do we build the chronology" to "how do we bridge the last gaps"?

\section{THE COMPLETION OF THE BELFAST LONG CHRONOLOGY}

Here it is necessary to introduce the issue of the German work. While the Irish chronology was being put together, workers at Köln (Burghart Schmidt) and Stuttgart (Bernd Becker) were working on a long German oak chronology. While they were using building and archaeological timbers for the $\mathrm{AD}$ era, for the prehistoric section most of their oak samples came from river gravels rather than peat bogs. These were trees that had grown on mineral soils along the edges of rivers and had been washed into the rivers where they were preserved. This meant that the Schmidt/Becker chronology was almost entirely constructed from land-grown trees in contrast to the Irish chronology that relied on bog-grown oaks.

Our first introduction to any of these German dendrochronologists had been in 1974 at the first International Tree-Ring Conference in Tucson. However, as far as possible we had tried not to cooperate too closely for the simple reason that we wanted to preserve the independence of both chronologies. This was an important issue because we were hopeful that we could use the completed German and Irish chronologies as a final check on each other (this would be tertiary replication, i.e. replication between the work of 2 independent laboratories).

To set the scene for the completion of both the Irish and German oak chronologies, we need to focus on the years 1980-1984. Around 1980, it had become very clear that 2 of the remaining gaps in the Irish chronology - for simplicity let us refer to them as gaps in the 1st and 10th centuries BC-were proving impossible to bridge using only Irish site chronologies. By this stage, the chronologies had names. The 4300-yr-long chronology section that spanned roughly 5300-1000 BC was known as the "Long Chronology"; the 719-yr-long section that appeared to fall somewhere between 1000 and 200 BC was named "Garry Bog II" because it was underpinned by large numbers of samples from Garry Bog, the largest peat bog in Northern Ireland. As more and more samples were collected, and crossdated, it was observed that we could add more and more samples to the young end of the Long Chronology and more and more to the old end of Garry Bog II, but we could not find any samples that linked between the 2 chronologies to form a bridge. We could be fairly sure from ${ }^{14} \mathrm{C}$ evidence that the ends of these chronologies were not far apart in time-indeed there might even be a short overlap, for all we knew. This caused us to imagine that perhaps some catastrophic event around $1000 \mathrm{BC}$ had depleted the bog-oak populations and that our random sampling might never provide the essential linkage. A very similar situation existed with respect to the last centuries $\mathrm{BC}$. We could duplicate the young end of Garry Bog II and the old end of the modern chronology that extended back to $13 \mathrm{BC}$, but we could not find any bog oaks to link between the two.

It was at this stage that 3 things happened, involving luck, wider sampling, and cooperation. First, we decided that the only solution to tying down the prehistoric Irish chronology sections might be to build several bog-oak chronologies in England and hope that these would act as stepwise links to the German chronology. This was regarded as inherently bad, because it would remove the possibility of independent replication of the Irish work; after all, if we built our chronology using German chronologies we could not use those same German chronologies to independently check our chronology. However, as a dozen years of work had failed to complete the Irish chronology, something had to be done. 
Secondly, we approached archaeological and tree-ring colleagues excavating or working on Roman sites in England - specifically Carlisle and London - to provide timbers or chronologies for the centuries between AD 200 and 200 BC, in the hope of using these to link across the 1st century BC gap. This approach led to the construction of a Roman chronology for Carlisle in northern England that spanned $247 \mathrm{BC}$ to AD 90. This Roman section was well replicated by a chronology from Roman London (kindly supplied by Jennifer Hillam, Cathy Groves, and Ian Tyers) that spanned 252 BC to AD 255.

Thirdly, we got lucky. Within the north of Ireland, the discovery of oak timbers at 2 Early Iron Age sites-Emain Macha (the ancient capital of Ulster at Navan Fort, County Armagh) and The Dorsey (an important banked enclosure related to the linear earthwork called the Black Pig's Dyke, County Armagh) - provided a 246-yr chronology that linked with and extended the Garry Bog II chronology forward to $116 \mathrm{BC}$ (later this would be extended further to $95 \mathrm{BC}$, but that is not relevant here), partially closing the $229 \mathrm{BC}$ to $13 \mathrm{BC}$ gap. Similarly, the chance find of a large heap of bog oaks at Swan Carr, in northeast England, provided a 775-yr chronology that linked across the gap between the Long Chronology and Garry Bog II. Just to keep the "lucky" nature of this exercise going, the "gap" between the 2 Irish chronologies turned out to be a single year. (We now know that the Swan Carr chronology spanned 1155 to $381 \mathrm{BC}$ and the LC/GBII gap was between 949 and 947 BC [Baillie et al. 1983].)

Putting these various components together, by 1982-83 the whole Irish Long Chronology project was essentially complete. The Long Chronology had been linked through Swan Carr to the Garry Bog II chronology that in turn was extended forward in time by the archaeological Navan/Dorsey chronology. Using the English Roman tree rings, the whole prehistoric Irish chronology was then linked to the modern Irish chronology that extended back to $13 \mathrm{BC}$. This suite of matches told us that the long bog-oak chronology ran from 5289 BC down to the end of Garry Bog II at 229 BC. All that was required was some tertiary replication against some completely independent German oak chronology; then the ${ }^{14} \mathrm{C}$ world would have its absolute Old World standard for calibration purposes.

\section{THE GERMAN SITUATION}

Although we had known the major German players since the 1970s, we had limited collaboration for the reasons already stated. Then, in 1982 Becker and Schmidt published an article indicating that a German oak chronology existed back to 2000 BC (Becker and Schmidt 1982). With the Irish Long Chronology apparently completed back to 5289 BC - thanks to those various English linkages - it was decided that it was time to attempt direct comparisons between the Irish and German prehistoric chronologies. This was carried out as follows. After initial contacts agreeing in principle to data exchange, both teams stripped out a millennium of their chronology from 2000-1000 BC and consigned it to the post. As soon as the 1000-yr chronology sections were compared it was immediately clear that there was an excellent correlation, despite the distance between the source areas. However, it was immediately clear that there was a problem with the dates. If we applied the dates attached to the German chronology to the Irish chronology at the matching position, it indicated that last ring of the Garry Bog II chronology lay not at $229 \mathrm{BC}$ as we believed, but at $158 \mathrm{BC}$; a discrepancy of 71 yr. This was an interesting situation for the following reasons.

One or other chronology had to be in error. The nightmare was this: If the German workers were correct then some of the Irish linkages had to be wrong. But all the Irish linkages satisfied the criteria we had established in house for accepting links. So, if the Germans were correct it was not simply that we might have made 1 mistake, the nightmare was that it called our procedures into question, and the whole Irish chronology could be called into question. However, we already knew that there 
was nothing wrong with our procedures because we had successfully made all the links back to 13 $\mathrm{BC}$, and that independent chronology had replicated through English to German chronologies (see Figure 1; Baillie et al. 1983). That implied that the error was most likely on the German side. Two things came to our rescue. First, Hans Suess had wiggle-matched sections of the German chronology to the bristlecone pine calibration curve and had shown an offset of around $70 \mathrm{yr}$, very close indeed to the observed 71-yr discrepancy with the Irish chronology (Becker 1983). Secondly, a close inspection of the German chronology showed that Becker and Schmidt had been forced to use Hollstein's Trier oak chronology to bridge a gap in their subfossil chronologies in the 6th century BC. Analysis of the Hollstein chronology showed just how weak that chronology was across the 6th century. Although the critical site (Kirnsulzbach) had produced 7 timbers with a total of 634 rings, Hollstein (1973) admitted that 13,000 measurements had been made on the fragmentary timbers. This knowledge, combined with the fact that the internal Hollstein linkages produced no significant correlations when the data was extracted and subjected to computer analysis, clearly defined that the 71-yr error was built into the German chronology when Schmidt and Becker used Hollstein's chronology to bridge their 6th century gap (Baillie 1982, 1983; Baillie and Pilcher 1987)

Putting these various strands together, it did not take long for the 4 principal players-Becker, Schmidt, Pilcher, and Baillie - to agree on the 71-yr error in the German oak chronology. This resulted in the joint publication of an agreed European oak chronology back to 5289 BC (Pilcher et al. 1984). Purists will note that this agreed chronology lacked tertiary replication simply because we had used the Irish chronology to correct the German chronology, meaning that there was no truly independent replication. However, as luck would have it, in 1984 Axel Delorme and Hubert Leuschner published their Göttingen oak chronology for the last $6000 \mathrm{yr}$ (Leuschner and Delorme 1984). A further exchange of data showed that the Belfast and Göttingen oak chronologies were in precise synchronization for the whole $6000 \mathrm{yr}$. This linkage was made possible by stepwise correlations from Ireland; through long sections of the English chronology from Croston Moss, Lancashire; to the north German Göttingen chronology with massively high correlations (see Figure 3).

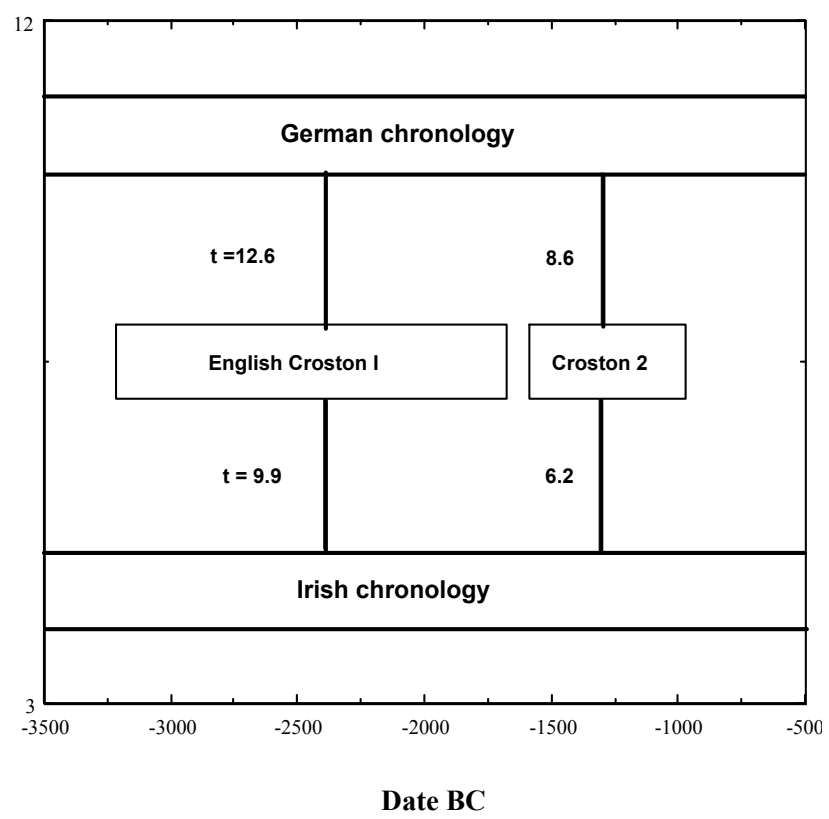

Figure 3 Stepwise correlations Ireland to England to Germany for the prehistoric period. 
With the European oak chronologies now forming an independently replicated system, it was possible to confirm the absolute calendar ages of all the oak calibration samples used by Minze Stuiver in Seattle and by Gordon Pearson in Belfast. By 1986, the Irish and German calibration curves were published (Pearson et al. 1986; Stuiver and Becker 1986) as well as an agreed joint calibration amalgamating the 2 calibration data sets (Pearson and Stuiver 1986; Stuiver and Pearson 1986). The Irish oak tree-ring chronology and the resultant Irish ${ }^{14} \mathrm{C}$ calibration were thus complete over 7 millennia (Brown et al. 1986).

\section{THE BONUS}

Whereas the bristlecone pine chronology was already in existence to provide American wood samples for the Suess calibration, the Irish oak chronology was built initially with the sole aim of allowing an independent ${ }^{14} \mathrm{C}$ calibration exercise. Once the chronology was complete it immediately represented an important direct dating tool for Irish archaeological timbers of all periods, back to the Mesolithic. Large numbers of Irish oak-bearing archaeological sites have been dated over the last 30 $\mathrm{yr}$ and these indicate patterns of activity that appear not to be random, but rather to be environmentally driven (Baillie and Brown 2002) (see Figure 4).

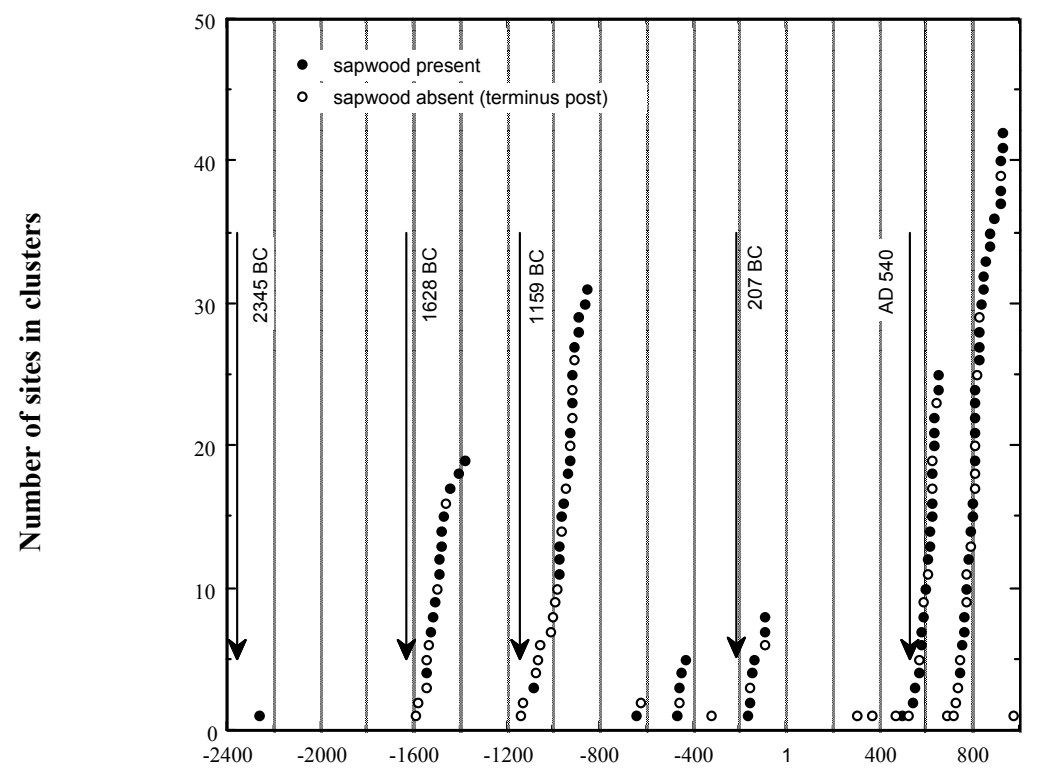

Date BC / AD

Figure 3 Distribution of dated archaeological oak timbers from Ireland showing clear clustering in time that is presumably environmentally driven. Arrows represent the abrupt environmental downturns referred to as "marker dates" in the text.

Moreover, the long chronology also represented an environmental tool for attempting to make some sense of the environmental history of Ireland. The principal breakthrough in this area followed directly from the observation of frost rings in the upper tree-line bristlecone pine chronology of LaMarche and Hirschboeck (1984). Their suggestion that the frost ring of $1627 \mathrm{BC}$ might represent the date of the Bronze Age eruption of Thera (Santorini) in the Aegean led directly to a search for extreme events in the Irish chronology. This resulted in a series of dates (e.g. 3195 BC, 2345 BC, 
1159 BC, 207 BC, and AD 540) that turned out to be potentially important "marker dates" in human history (Baillie and Munro 1988; Baillie 1995; see also Hammer et al. 1987). It is unlikely these would ever have been found without LaMarche and Hirschboeck's 1627 BC Theran suggestion. As it is, they have led to the publication of at least 4 books and numerous articles involving volcanic and cosmic catastrophism, and even Irish mythology!

It also became apparent with the completion of the Irish and German oak chronologies that England was in danger of being left behind in terms of absolute chronology. So in the later 1980s, building on the chronology sections already constructed from Swan Carr and Croston Moss, effort was put into the completion of a long English prehistoric chronology. This effort was greatly helped because workers at Liverpool and Cambridge had already stockpiled large numbers of naturally preserved bog oaks from Lancashire and East Anglia, respectively. By 1989, a continuous English oak chronology was available back to 4989 BC (Brown and Baillie 1992).

\section{CONCLUSION}

Quite apart from the information that has become available from the initial ${ }^{14} \mathrm{C}$ calibration exercise-something that has been extended into areas such as interhemispheric calibration (McCormac et al. 1998) - the work has also given rise to studies of regional ${ }^{14} \mathrm{C}$ offsets (McCormac et al. 1995). The dendrochronological bonuses continue to develop. The recognition of volcano-related downturns in the tree-ring chronologies offer the possibility of linking spaced events in the tree-ring records to spaced acidities in the Greenland ice cores (Baillie 1996, 2008). The availability of a widespread grid of tree-ring chronologies worldwide has led to the first recognition of "global environmental events," a concept previously totally missing from history (due to the poor geographical coverage of historical sources; their general failure to record environmental information; and the antipathy of historians and archaeologists to issues that might smack of environmental determinism). The first well-documented global environmental downturn spans AD 536-550 and involves cold, famine, and plague (Baillie 1994). It shows up in tree-ring chronologies from both the Old and New Worlds. It has recently been shown to involve either a single massive volcanic eruption in AD 536 (Larsen et al. 2008) or 2 eruptions, one in 536 and a second (the massive one) in 540-541 (Baillie 2008). However, a third possibility cannot currently be ruled out, namely a massive eruption in 536 and a cosmic impact around 540 (Baillie 2008). Only a final resolution of the issue of ice-core chronology can allow a full understanding of the exact sequence of events at that time.

Overall, the construction of an Irish oak chronology to facilitate ${ }^{14} \mathrm{C}$ calibration has unleashed a broad suite of studies that have taken researchers into undreamt-of areas of research. It would be possible to argue that some of these other applications, such as the isolation of global environmental events, are of more importance than the initial ${ }^{14} \mathrm{C}$ calibration. It has to be remembered that no amount of ${ }^{14} \mathrm{C}$ calibration allows the isolation of absolute calendar dates-something implicit in dendrochronology. The discipline of archaeology finds great difficulty in contributing to the "global event" debates that have now been generated by dendrochronology; their chronologies, calibrated or otherwise, are not sufficiently resolved to allow significant input. However, dendrochronologists in Europe (Baillie and Brown 2002) and the American Southwest (Robinson and Cameron 1991), through their ability to date large numbers of wood-bearing archaeological sites, have allowed the effects of the AD 536-550 global event to be clearly observed (Baillie 1995: Figure 6.6). In a nutshell, although the tree-ring chronologies were constructed to improve archaeological chronology through calibration, the tree-ring chronologies now raise questions that archaeologists find difficulty in answering. From that perspective, the calibration exercises unleashed what can only be termed $a$ dendrochronological monster. 


\section{ACKNOWLEDGMENTS}

Without the inspiration and foresight of Profs Alan Smith and Jon Pilcher in the years 1966-68, almost none of the research in this paper would ever have taken place. The author would like to acknowledge all those who assisted in the construction of the long Irish and English oak chronologies, including the numerous landowners who allowed the sampling of their oaks both modern and ancient, the numerous assistants who helped with both field- and laboratory work, the archaeological and other colleagues who supplied historical and archaeological samples, and the many dendrochronological colleagues who helped with samples and data. The work would not have been possible without the financial support of the Queen's University of Belfast and the Science and Engineering Research Council of the UK.

\section{REFERENCES}

Baillie MGL. 1982. Tree-Ring Dating and Archaeology. London: Croom Helm. 274 p.

Baillie MGL. 1983. Belfast dendrochronology - the current situation. In: Ottaway BS, editor. Archaeology, Dendrochronology and the Radiocarbon Calibration Curve. Occasional Paper No. 9, University of Edinburgh. p 15-24.

Baillie MGL. 1994. Dendrochronology raises questions about the nature of the AD 536 dust-veil event. The Holocene 4(2):212-7.

Baillie MGL. 1995. A Slice Through Time: Dendrochronology and Precision Dating. London: Routledge. $176 \mathrm{p}$.

Baillie MGL. 1996. Extreme environmental events and the linking of the tree-ring and ice-core records. In: Dean JS, Meko DM, Swetnam TW, editors. Tree Rings, Environment and Humanity. Tucson, Arizona, USA: Radiocarbon. p 703-11.

Baillie MGL. 2008. Proposed re-dating of the European ice core chronology by seven years prior to the 7th century AD. Geophysical Research Letters 35: L15813, doi:10.1029/2008GL034755.

Baillie MGL, Brown DM. 2002. Oak dendrochronology: some recent archaeological developments from an Irish perspective. Antiquity 76(292):497-505.

Baillie MGL, Munro MAR. 1988. Irish tree rings, Santorini and volcanic dust veils. Nature 332(6162):344-6.

Baillie MGL, Pilcher JR. 1973. A simple cross-dating program for tree-ring research. Tree-Ring Bulletin 33: $7-14$.

Baillie MGL, Pilcher JR. 1987. The Belfast "Long Chronology” Project. British Archaeological Reports (International Series 333). p 203-14

Baillie MGL, Pilcher JR, Pearson GW. 1983. Dendrochronology at Belfast as a background to high-precision calibration. Radiocarbon 25(2):171-8.

Becker B. 1983. The long-term radiocarbon trend of the absolute German oak tree-ring chronology, 2800 to 800 BC. Radiocarbon 25(2):197-203.

Becker B, Schmidt B. 1982. Verlangerung der Mitteleuropaischen Eichenjahrringchronologie in das Zweite Vorchristliche Jahrtausand (bis 1462 Chr.). Archäologisches Korrespondenzblatt 12:101-6.
Brown DM, Baillie MGL. 1992. Construction and dating of a 5000 year English bog oak tree-ring chronology. Lundqua Report 34:72-5.

Brown DM, Munro MAR, Baillie MGL, Pilcher JR. 1986. Dendrochronology - the absolute Irish standard. Radiocarbon 28(2A):279-83.

Douglass AE. 1919. Climatic Cycles and Tree Growth. Volume 1. Publication no. 289. Washington, DC: Carnegie Institution. $127 \mathrm{p}$.

Eckstein D, Bauch J. 1969. Beitrag zu Rationalisierung eines dendrochronologischen Verfahrens und zur Analyse seiner Aussagesicherheit. Forstwissenschaftliches Centralblatt 88(1):230-50. In German.

Hammer CU, Clausen HB, Friedrich WL, Tauber H. 1987. The Minoan eruption of Santorini in Greece dated to 1645 BC? Nature 328(6130):517-9.

Hollstein E. 1965. Jahrringchronologische von Eichenholzern ohne Waldkande. Bonner Jahrbuch 165:1227. In German.

Hollstein E. 1973. Jahrringkurven der Hallstattzeit. Trierer Zeitschrift 36:37-55. In German.

Hollstein E. 1980. MittelEuropaische Eichenchronologie. Mainz am Rhein: Phillip Von Zabern. In German.

Huber B, Giertz V. 1969. Our 1000 year oak chronology. Conference Report of the Austrian Academy of Sciences 178:32-42.

LaMarche Jr VC, Hirschboeck KK. 1984. Frost rings in trees as records of major volcanic eruptions. Nature 307(5947):121-6.

Larsen LB, Vinther BM, Briffa KR, Melvin TM, Clausen HB, Jones PD, Siggaard-Andersen M-L, Hammer CU, Eronen M, Grudd H, Gunnarson BE, Hantemirov RM, Naurbaev MM, Nicolussi K. 2008. New ice core evidence for a volcanic cause of the A.D. 536 dust veil. Geophysical Research Letters 35: L04708, doi: 10.1029/2007GL032450.

Leuschner HH, Delorme A. 1984. Verlangerung der Gottingen Eichenjahrringchronologien fur Nord- und Suddeutschland bis zum Jahr 4008 v. Chr. Forstarchiv 55:1-4. In German.

McCormac FG, Baillie MGL, Pilcher JR, Kalin RM. 1995. Location-dependent differences in the ${ }^{14} \mathrm{C}$ content of wood. Radiocarbon 37(2):395-407. 
McCormac FG, Hogg AG, Higham TFG, Lynch-Stieglitz J, Broecker WS, Baillie MGL, Palmer J, Xiong L, Pilcher JR, Brown D, Hoper ST. 1998. Temporal variation in the interhemispheric ${ }^{14} \mathrm{C}$ offset. Geophysical Research Letters 25(9):1321-4.

Munro MAR. 1984. An improved algorithm for crossdating tree-ring series. Tree-Ring Bulletin 44:17-27.

Pearson GW. 1980. High precision radiocarbon dating by liquid scintillation counting applied to radiocarbon time-scale measurements. Radiocarbon 22(2):33745.

Pearson GW, Stuiver M. 1986. High-precision calibration of the radiocarbon time scale, 500-2500 BC. Radiocarbon 28(2B):839-62.

Pearson GW, Pilcher JR, Baillie MGL, Corbett DM, Qua F. 1986. High-precision ${ }^{14} \mathrm{C}$ measurement of Irish oaks to show the natural ${ }^{14} \mathrm{C}$ variations from $\mathrm{AD} 1840$ to 5210 BC. Radiocarbon 28(2B):911-34.

Pilcher JR, Baillie MGL, Schmidt B, Becker B. 1984. A 7,272-year tree-ring chronology for western Europe. Nature 312(5990):150-2.

Robinson WR, Cameron CM. 1991. A Directory of TreeRing Dated Prehistoric Sites in the American South- west. Tucson, Arizona, USA: University of Arizona, Laboratory of Tree-Ring Research.

Smith AG, Baillie MGL, Hillam J, Pilcher JR, Pearson GW. 1972. Dendrochronological work in progress in Belfast: the prospect for an Irish post-glacial tree-ring sequence. Proceedings of the 8th International Conference on Radiocarbon Dating. Lower Hutt, New Zealand. A92-95.

Stokes MA, Smiley TL. 1968. An Introduction to TreeRing Dating. Chicago: University of Chicago Press. $73 \mathrm{p}$.

Stuiver M, Becker B. 1986. High-precision decadal calibration of the radiocarbon time scale, AD 1950-2500 BC. Radiocarbon 28(2B):863-91.

Stuiver M, Pearson GW. 1986. High-precision calibration of the radiocarbon time scale AD 1950-500 BC. Radiocarbon 28(2B):805-38.

Suess HE. 1970. Bristlecone pine calibration of the radiocarbon time-scale from $5200 \mathrm{BC}$ to the present. In: Olsson IU, editor. Radiocarbon Variations and Absolute Chronology. New York: John Wiley and Sons. p 303-9. 